Article

\title{
Convenient Asymmetric Synthesis of Fmoc-(S)-6,6,6-Trifluoro-Norleucine
}

\author{
Haibo Mei ${ }^{1}{ }^{1}$, Zizhen Yin ${ }^{1}$, Toshio Miwa ${ }^{2}$, Hiroki Moriwaki ${ }^{2, *}$, Hidenori Abe ${ }^{2}$, \\ Jianlin Han 1,*(D) and Vadim A. Soloshonok ${ }^{3,4, * \mathbb{D}}$ \\ 1 Jiangsu Co-Innovation Center of Efficient Processing and Utilization of Forest Resources, \\ College of Chemical Engineering, Nanjing Forestry University, Nanjing 210037, China; \\ meihb@njfu.edu.cn (H.M.); Yin.zizhen1996@outlook.com (Z.Y.) \\ 2 Hamari Chemicals Ltd., 1-4-29 Kunijima, Higashi-Yodogawa-ku, Osaka 533-0024, Japan; \\ toshio-miwa@hamari.co.jp (T.M.); hidenori-abe@hamari.co.jp (H.A.) \\ 3 Department of Organic Chemistry I, Faculty of Chemistry, University of the Basque Country UPV/EHU, \\ Paseo Manuel Lardizábal 3, 20018 San Sebastián, Spain \\ 4 IKERBASQUE, Basque Foundation for Science, María Díaz de Haro 3, Plaza Bizkaia, 48013 Bilbao, Spain \\ * Correspondence: hiroki-moriwaki@hamari.co.jp (H.M.); hanjl@njfu.edu.cn (J.H.); \\ vadym.soloshonok@ehu.es (V.A.S.)
}

Received: 8 April 2019; Accepted: 18 April 2019; Published: 21 April 2019

\begin{abstract}
In this work we report a convenient asymmetric synthesis of Fmoc-(S)-6,6,6-trifluoronorleucine via alkylation reaction of chiral glycine equivalent. The target amino acid of $99 \%$ enantiomeric purity was prepared with $82.4 \%$ total yield (three steps).
\end{abstract}

Keywords: fluorine; amino acids; alkylation; asymmetric synthesis; $\mathrm{Ni}(\mathrm{II})$ complexes

\section{Introduction}

Medicinal applications of new organic compounds have always been a major driving force behind the development of organic methodology. In this regard, one can notice two general trends in the design of modern pharmaceutical drugs: the introduction of fluorine-containing substituents and tailor-made amino acids (AAs) [1-10]. While the strategic fluorination usually leads to improved pharmacokinetics and greater oxidative metabolic stability $[9,11,12]$, the presence of tailor-made amino AAs residues allows for more precise mimicking of the natural peptide-receptor interactions [1-8]. Subsequently, fluorine-containing $\alpha$ - [13-21] and $\beta$-AAs [22-24], featuring both structural traits, are currently an increasingly important class of compounds used in bio-medicinal studies and drug design [25-28]. For example, (S)-2-amino-6,6,6-trifluorohexanoic acid and 6,6,6-trifluoro-norleucine 1 (Scheme 1) and its derivatives were shown to possess interesting biological properties, such as antitumor [29], antimicrobial [30], and enzyme inhibitory activity [31,32]. However, the major interest in fluorinated AA 1 is related to its various applications in the therapeutic peptide engineering [33-36] and protein structural studies [37-39]. Over the last decade, various synthetic approaches for preparation of tailor-made fluorinated norleucine $\mathbf{1}$ have received due attention. One group of the methods is based on elaboration of functional groups in the already prearranged AA skeleton 2, such as additions of $\mathrm{CF}_{3}$ radical to the terminal $\mathrm{C}=\mathrm{C}$ bond $[40,41]$ or biomimetic transamination $[42,43]$. However, a more general approach for synthesis of AA 1 includes alkyl halide alkylation of properly protected glycine derivatives 3 [44-48]. These reactions can be conducted under homogeneous [45-48], as well as PTC conditions [44]. 
<smiles>[Y][X](C)(C)CC(=O)CN</smiles>

3

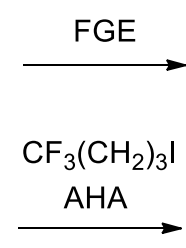

$\mathrm{X}=$ Properly protected $\mathrm{COOH}$ and $\mathrm{NH}_{2}$ groups

$\mathrm{FGE}=$ Functional group elaborations.

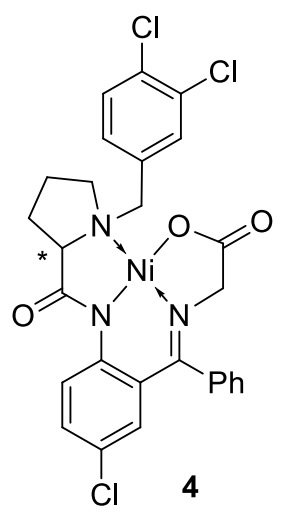

$\mathrm{AHA}=$ Alkyl halide alkylations

Scheme 1. Literature methods for synthesis of 6,6,6-trifluoro-norleucine (1) via functional group elaborations (FGE) in 2 and alkyl halide alkylations (AHA) of glycine derivatives (3). Application of chiral $\mathrm{Ni}(\mathrm{II})$ complexes (4) for preparation of $\mathbf{1}$ via AHA.

In this paper we describe a convenient asymmetric synthesis of Fmoc derivative 6,6,6-trifluoronorleucine 1 via $\mathrm{CF}_{3}\left(\mathrm{CH}_{2}\right)_{3}$ I alkylation of the recently rationally designed chiral equivalent of nucleophilic glycine 4 . The method is operationally convenient, robust, scalable, and can be recommended for practical preparation of enantiomerically pure ( $\sim 99 \%$ ee) derivative of this important tailor-made AA.

\section{Materials and Methods}

General Methods. All solvents and reagents were used as purchased without further purification. All reactions were conducted by magnetically stirring and detected by routine chromatography on TLC plates. Flash chromatography was carried out using the corresponding solvents on silica gel $(0.064-0.210 \mathrm{~mm})$. The reported yields are for isolated and chemically pure compounds. HPLC experiments were performed on a standard equipment using the Inertsil ${ }^{\mathrm{TM}}$ ODS- 3 column $(3 \mu \mathrm{m}$, $150 \times 4.6 \mathrm{~mm}$ ) ran at $1.0 \mathrm{~mL} / \mathrm{min}, 30{ }^{\circ} \mathrm{C}$; monitoring was set at $254 \mathrm{~nm}$ with a gradient of $10 \mathrm{mM}$ aqueous $\mathrm{HCOOH} / \mathrm{NH}_{3}$ containing $0.1 \% \mathrm{HCOOH}$ (eluent $\mathrm{A}$ ) and $\mathrm{MeCN}$ (eluent $\mathrm{B}$ ) from $\mathrm{A}: \mathrm{B}=95: 5$ to 20:80 and 20:80. ${ }^{1} \mathrm{H}-,{ }^{19} \mathrm{~F}-$, and ${ }^{13} \mathrm{C}-\mathrm{NMR}$ data were recorded on Bruker AVANCE III-400 instrument. Chemical shifts are presented in ppm (d), referenced to $\mathrm{SiMe}_{4}$ (TMS). Optical rotations data were conducted on a DIP-370 instrument. Melting points were taken as usual.

Alkylation Reaction of Glycine Complex (S)-4 with $\mathrm{CF}_{3}\left(\mathrm{CH}_{2}\right)_{3} \mathrm{I}$. The Ni-glycine complex (S)-4 ( $20.0 \mathrm{~g}, 33.2 \mathrm{mmol}, 1.0$ equiv.) and 1,1,1-trifluoro-4-iodobutane $(7.90 \mathrm{~g}, 33.2 \mathrm{mmol}, 1.0$ equiv.) were stirred in deoxygenated $\mathrm{N}, \mathrm{N}$-dimethyl-formamide (DMF) $(140 \mathrm{~mL}, 7 \mathrm{v} / \mathrm{w})$ at room temperature under argon. Then, $10 \%$ NaOMe methanol solution (1.0 equiv.) was added into the above mixture. The resulting solution was stirred at room temperature for $2 \mathrm{~h}$, and then was poured into water $(46 \mathrm{~mL})$ at same temperature to give the precipitate. After $0.5 \mathrm{~h}$, the mixture was added water $(24 \mathrm{~mL})$, and was stirred

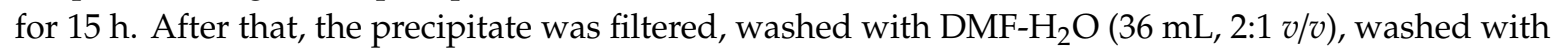
water $(40 \mathrm{~mL})$ and dried in vacuo at $60^{\circ} \mathrm{C}$ for $7 \mathrm{~h}$ to afford the crude Ni complex $(20.8 \mathrm{~g}, 87.9 \%$, a red solid) as a mixture of $(S, 2 S)-6$ and $(S, 2 R)-7$, the diastereomeric ratio was determined to be $(98.7 \% d e)$ by HPLC analysis, in which the major $(S, 2 S)-6$ was eluted at a retention time $\left(t_{R}\right)$ of $20.3 \mathrm{~min}$ and the minor $(S, 2 R)-7$ at 21.5 min under the conditions described in the general methods. The mixture of 6 and 7 was purified by column to give the diastereomerically pure major product 6 in $87.5 \%$ yield (see Supplementary Materials).

$(S, 2 S)-6$ (major isomer): M.p. $229-231{ }^{\circ} \mathrm{C} .[\alpha]^{25} \mathrm{D}=+2616\left(\mathrm{c}=0.2, \mathrm{CH}_{3} \mathrm{OH}\right) \cdot{ }^{1} \mathrm{H}$ NMR $(400 \mathrm{MHz}$, $\left.\mathrm{CDCl}_{3}\right): \delta=8.89(\mathrm{~d}, J=1.6 \mathrm{~Hz}, 1 \mathrm{H}), 8.09(\mathrm{~d}, J=9.2 \mathrm{~Hz}, 1 \mathrm{H}), 7.77(\mathrm{dd}, J=1.7,8.1 \mathrm{~Hz}, 1 \mathrm{H}), 7.49-7.58$ $(\mathrm{m}, 3 \mathrm{H}), 7.37(\mathrm{~d}, J=8.1 \mathrm{~Hz}, 1 \mathrm{H}), 7.29-7.30(\mathrm{~m}, 1 \mathrm{H}), 7.11(\mathrm{dd}, J=2.4,9.2 \mathrm{~Hz}, 1 \mathrm{H}), 6.88(\mathrm{~d}, J=7.5 \mathrm{~Hz}$, $1 \mathrm{H}), 6.59(\mathrm{~d}, J=2.4 \mathrm{~Hz}, 1 \mathrm{H}), 4.34(\mathrm{~d}, J=12.6 \mathrm{~Hz}, 1 \mathrm{H}), 3.87(\mathrm{dd}, J=8.0,3.4 \mathrm{~Hz}, 1 \mathrm{H}), 3.51-3.57(\mathrm{~m}, 2 \mathrm{H})$, $3.35-3.39(\mathrm{~m}, 1 \mathrm{H}), 3.21(\mathrm{~d}, J=12.6 \mathrm{~Hz}, 1 \mathrm{H}), 2.59-2.71(\mathrm{~m}, 2 \mathrm{H}), 2.35-2.37(\mathrm{~m}, 1 \mathrm{H}), 2.24-2.25(\mathrm{~m}, 1 \mathrm{H})$, 
1.84-2.08 (m, 3H), 1.82-1.84 (m, 2H), 1.60-1.66 (m, 1H). ${ }^{13} \mathrm{C} \mathrm{NMR}\left(100 \mathrm{MHz}, \mathrm{CDCl}_{3}\right): \delta=18.0,23.5,30.8$ $32.6(J=29.0 \mathrm{~Hz}, \mathrm{q}), 34.1,58.3,63.0,69.7,71.3,124.1,125.3(J=276.6 \mathrm{~Hz}, \mathrm{q}), 125.7,127.0,127.1,127.2$, $129.3,129.4,129.8,130.3,132.1,132.4,132.7,133.3,133.5,133.6,134.8,140.5,170.4,178.3,179.9 .{ }^{19} \mathrm{~F}$ NMR $\left(376 \mathrm{MHz}, \mathrm{CDCl}_{3}\right): \delta=-66.8\left(\mathrm{CF}_{3}\right) . \mathrm{IR}(\mathrm{KBr}): v=2977,1674,1650,1535,1463,1398,1251,1188,1077$, $826 \mathrm{~cm}^{-1}$. MS (ESI): $\mathrm{m} / z=710.1[\mathrm{M}+\mathrm{H}]^{+}$.

$(S, 2 R)-7$ (minor isomer): M.p. $218-220{ }^{\circ} \mathrm{C} .[\alpha]^{25} \mathrm{D}=-1998\left(\mathrm{c}=0.2, \mathrm{CH}_{3} \mathrm{OH}\right) \cdot{ }^{1} \mathrm{H}$ NMR $(400 \mathrm{MHz}$, $\left.\mathrm{CDCl}_{3}\right): \delta=8.50(\mathrm{~d}, J=9.2 \mathrm{~Hz}, 1 \mathrm{H}), 8.37(\mathrm{~d}, J=2.0 \mathrm{~Hz}, 1 \mathrm{H}), 7.74(\mathrm{dd}, J=2.0,8.0 \mathrm{~Hz}, 1 \mathrm{H}), 7.03-7.23$ $(\mathrm{m}, 4 \mathrm{H}), 7.20-7.23(\mathrm{~m}, 2 \mathrm{H}), 7.00-7.03(\mathrm{~m}, 1 \mathrm{H}), 6.72(\mathrm{~d}, J=2.4,1 \mathrm{H}), 4.24-4.30(\mathrm{~m}, 2 \mathrm{H}), 3.71(\mathrm{dd}, J=10.0$, $3.2 \mathrm{~Hz}, 1 \mathrm{H}), 3.55(\mathrm{dd}, J=8.8,4.4 \mathrm{~Hz}, 1 \mathrm{H}), 3.35-3.38(\mathrm{~m}, 1 \mathrm{H}), 2.62-2.67(\mathrm{~m}, 2 \mathrm{H}), 2.25-2.30(\mathrm{~m}, 2 \mathrm{H})$, $1.80-2.00(\mathrm{~m}, 2 \mathrm{H}), 1.64-1.79(\mathrm{~m}, 3 \mathrm{H}), 1.25-1.35(\mathrm{~m}, 2 \mathrm{H}) .{ }^{13} \mathrm{C} \mathrm{NMR}\left(100 \mathrm{MHz}, \mathrm{CDCl}_{3}\right): \delta=18.3,23.1,30.3$ $32.2(J=29.0 \mathrm{~Hz}, \mathrm{q}), 35.1,59.5,60.5,69.2,69.7,125.0,125.4(J=276.6 \mathrm{~Hz}, \mathrm{q}), 125.7,126.6,126.7,127.6$, 129.1, 129.5, 130.2, 130.5, 132.3, 132.5, 133.2, 133.3, 133.4, 133.8, 133.9, 141.3, 170.9, 178.9, 181.5. ${ }^{19}$ F NMR $\left(376 \mathrm{MHz}, \mathrm{CDCl}_{3}\right): \delta=-66.6\left(\mathrm{CF}_{3}\right) . \mathrm{IR}(\mathrm{KBr}): v=2945,1676,1644,1584,1464,1395,1247,1135,1029$, $823 \mathrm{~cm}^{-1}$.

Preparation of Fmoc-(S)-2-amino-6,6,6-trifluorohexanoic acid (S)-9. To a solution of Ni complex $(S, 2 S)-6$ (20.0 g, $28.1 \mathrm{mmol}, 1.0$ equiv.) in dimethoxyethane (DME) $(100 \mathrm{~mL}, 5 \mathrm{v} / \mathrm{w})$ was added $\mathrm{HCl}$ $\left(3 \mathrm{~N}, 46.8 \mathrm{~mL}, 5.0\right.$ equiv.), and the resulting mixture was heated at $50-60{ }^{\circ} \mathrm{C}$ for $2 \mathrm{~h}$. Then, the reaction mixture was cooled to room temperature, and the the reaction mixture was evaporated to remove DME. Water $(400 \mathrm{~mL})$ was added, and white precipitate $(\mathrm{HCl}$ salt $)$ appeared. The precipitate was filtered, washed with water $(20 \mathrm{~mL} \times 2)$. The filtrate was total $80 \mathrm{~mL}$.

To the above (S)-6,6,6-trifluoro-norleucine $\mathrm{HCl}$ green solution were added ethylenediaminetetraacetic acid disodium salt hydrate $(10.5 \mathrm{~g}, 1.0$ equiv) and acetonitrile $(60 \mathrm{~mL})$ and the mixture was stirred for $0.5 \mathrm{~h}$ at room temperature; $48 \% \mathrm{NaOH}$ ( $9.5 \mathrm{~g}, 4.1$ equiv) was added. Then, sodium carbonate $(3.87 \mathrm{~g}$, 1.3 equiv) and Fmoc-OSu ( 9.48 g, 1.0 equiv.) were added to the resulting mixture. The mixture was stirred for $3 \mathrm{~h}$ at room temperature, and then was concentrated. To the residue was added ethyl acetate $(100 \mathrm{~mL})$ and $\mathrm{HCl}(6 \mathrm{~N}, 20.0 \mathrm{~mL})$, and the phases were separated. The aqueous layer was extracted with ethyl acetate $(40 \mathrm{~mL})$ and the combined organic layer was washed with water $(40 \mathrm{~mL})$ and $10 \%$ brine $(40 \mathrm{~mL})$. The organic solution was dried with $\mathrm{Na}_{2} \mathrm{SO}_{4}$, and then the filtrate was concentrated to dryness and dried in vacuo at $50{ }^{\circ} \mathrm{C}$ to afford (S)-9 (11.45 g, a white powder) (see Supplementary Materials).

(S)-9: M.p. 152-154 ${ }^{\circ} \mathrm{C} .{ }^{1} \mathrm{H}$ NMR $\left(400 \mathrm{MHz}, \mathrm{CD}_{3} \mathrm{OD}\right): \delta=7.77-7.79(\mathrm{~m}, 2 \mathrm{H}), 7.64-7.69(\mathrm{~m}, 2 \mathrm{H})$, 7.32-7.40 (m, 2H), 7.28-7.30 (m, 2H), 4.36-4.37 (m, 2H), 4.18-4.24 (m, 2H), 2.18-2.23 (m, 2H), 1.92-1.95 $(\mathrm{m}, 1 \mathrm{H}), 1.64-1.77(\mathrm{~m}, 2 \mathrm{H}) .{ }^{19} \mathrm{~F} \mathrm{NMR}\left(376 \mathrm{MHz}, \mathrm{CDCl}_{3}\right): \delta=-67.6\left(\mathrm{CF}_{3}\right) . \mathrm{IR}(\mathrm{KBr}): v=3265,3067,2926$, $2858,1654,1476,1445,1049 \mathrm{~cm}^{-1}$. MS (ESI): $\mathrm{m} / z=431.1[\mathrm{M}+\mathrm{Na}]^{+}$.

\section{Results and Discussion}

In line with our longstanding curiosity in synthesis of several types of tailor-made AAs, in particular trifluoromethyl- and [49,50] phosphorus-containing [51,52], sterically constrained [53,54], and nonlinear optical properties of AA and their derivatives, such as self-disproportionation of enantiomers [55-57], we were contributing to the chemistry of $\mathrm{Ni}$ (II) complexes of Schiff bases of AA as a general methodology for synthesis of tailor-made AAs [58-60]. Over the last several years, we were focusing on the modular design [61,62] of chiral tridentate ligands used for preparation of the corresponding $\mathrm{Ni}(\mathrm{II})$ complexes of AA Schiff bases. Among other advances [63-65], recently we developed a strategically trichloro-substituted ligand 5 (Scheme 2) [66,67], which showed excellent stereocontrolling properties in the dynamic kinetic resolution of unprotected $\alpha$ - $[68,69]$ and $\beta$-AAs [70]. It was shown that the presence of strategically positioned chlorine atoms favorably influence the parallel displaced type of aromatic stacking interactions between the proline $\mathrm{N}$-benzyl and o-amino-benzophenone ring [66]. The quality of these aromatic stacking has important synthetic consequences [67] enhancing the stereochemical preferences at the a-position of the amino acid residue. It should be mentioned that the strategically chlorinated ligand $\mathbf{5}$ was developed by and commercially available from Hamari Chemicals. However, other methodological avenues of ligand $\mathbf{5}$ applications for the asymmetric 
preparation of tailor-made AAs still remain unexplored [71]. Ligands $(S)$ - or $(R)-\mathbf{5}$ are commercially available and can be conveniently prepared [72] starting form $(S)$ - or $(R)$-proline and transformed to the $\mathrm{Ni}(\mathrm{II})$ complexes of glycine Schiff base 4 [71,73]. As presented in Scheme 2, ligand 5 is reacting with glycine and $\mathrm{Ni}(\mathrm{II})$ ions in basic methanol solution to afford complex 4 .

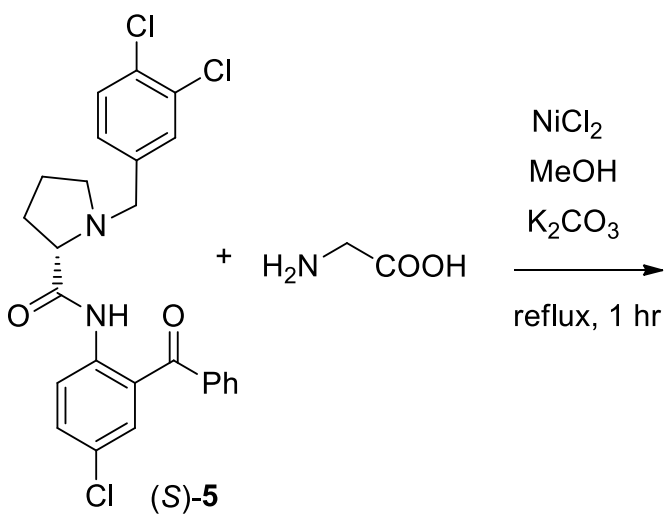

Scheme 2. Synthesis of chiral Ni(II) complex of glycine Schiff base 4 .

Alkylation of the glycine moiety in complexes of type 4 with alkyl halide as alkyl precursor can be conducted under homogeneous [74] as well as phase-transfer catalysis (PTC) conditions [75]. The latter are usually preferred, due to the low byproducts formation, but can be realized only for activated alkyl halides. Thus, under standard PTC conditions [75], $\mathrm{CF}_{3}\left(\mathrm{CH}_{2}\right)_{3} \mathrm{I}$ was found to be totally inefficient for alkylation of complex (S)-4, resulting in noticeable decomposition of the alkylating reagent. In sharp contrast, under the homogeneous conditions (Scheme 3), by use of DMSO as a solvent and $\mathrm{NaOH}$ as a base (Table 1), the expected alkylation products were isolated and fully characterized.

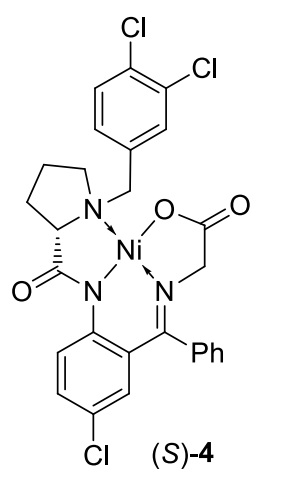

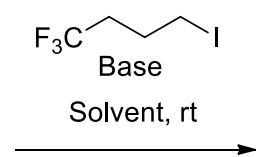

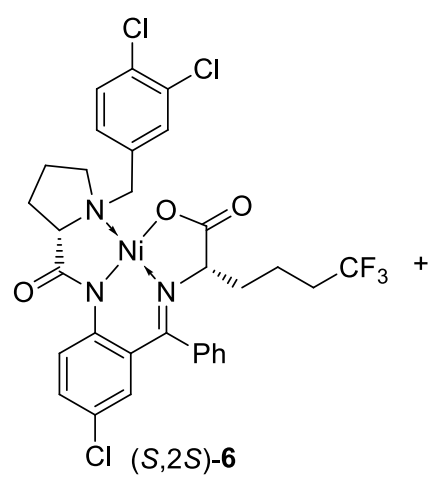

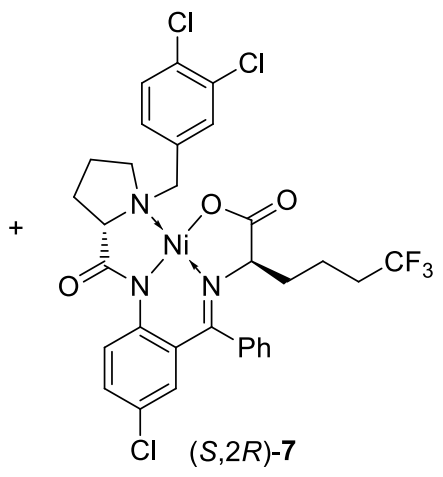<smiles>Clc1ccc2nc(C3CCCN3Cc3ccc(Cl)c(Cl)c3)nc(-c3ccccc3)c2c1</smiles>

Scheme 3. Alkylation of (S)-3 with $\mathrm{CF}_{3}\left(\mathrm{CH}_{2}\right)_{3} \mathrm{I}$ under homogeneous conditions.

HPLC analysis of the reaction mixture revealed rather low rate of the alkylation and disappointing diastereoselectivity. As shown in Table 1, in entries 1-3, after $4.5 \mathrm{~h}$ of the reaction time, over $43 \%$ of 
starting complex 4 was still intact. Near-complete consumption of glycine complex 4 was observed after $24 \mathrm{~h}$ (entry 4 ) along with a large amount of various byproducts. One of the major byproducts was identified as previously described [73] compound 8 resulting from oxidative decomposition of stating glycine complex $4[76,77]$.

Table 1. Reaction of complex (S)-4 with $\mathrm{CF}_{3}\left(\mathrm{CH}_{2}\right)_{3} \mathrm{I}$ in DMSO using solid $\mathrm{NaOH}$ as a base ${ }^{\text {[a] }}$.

\begin{tabular}{cccccccc}
\hline & \multicolumn{3}{c}{ Compounds } & \multicolumn{2}{c}{ Byproducts } \\
\hline Entry & Time (h) & $\mathbf{4 ( \% )}$ & $\mathbf{6 ~ ( \% )}$ & $\mathbf{7 ~ ( \% )}$ & Dr (6:7) & $\mathbf{5 ~ ( \% )}$ & $\mathbf{8 + \mathbf { u k } ^ { [ \mathbf { b } ] } \mathbf { ( \% ) }}$ \\
\hline 1 & 1.5 & 63.9 & 21.7 & 4.0 & $84: 16$ & 0.7 & 3.0 \\
\hline 2 & 3.0 & 54.5 & 25.7 & 4.7 & $85: 15$ & 0.4 & 5.1 \\
\hline 3 & 4.5 & 43.6 & 27.8 & 5.3 & $84: 16$ & 0.6 & 8.9 \\
\hline 4 & 24.0 & 0.7 & 37.9 & 2.1 & $95: 5$ & 5.1 & 42.5 \\
\hline
\end{tabular}

[a] Reaction conditions: complex (S)-4, DMSO (20 v/w), $\mathrm{NaOH}$ (1.0 equiv), $\mathrm{CF}_{3}\left(\mathrm{CH}_{2}\right) \mathrm{I}$ (1.0 equiv). ${ }^{[b]}$ unknown compounds.

One of the critical notes made in this series of experiment was the observation that solid $\mathrm{NaOH}$ is not the best choice of introducing the base into the reaction mixture. After a series of experiments focused on solvent/base issue, we found that combination of DMF as a reaction solvent and solution of $\mathrm{NaOMe}$ in $\mathrm{MeOH}$ as a base allows for a dramatically improved outcome. Thus, as presented in Table 2, the alkylation of (S)-4 with $\mathrm{CF}_{3}\left(\mathrm{CH}_{2}\right)_{3} \mathrm{I}$ performed in DMF and using $\mathrm{NaOMe} / \mathrm{MeOH}(28 \%$ solution) proceeded with high rate providing for virtually complete $(>99 \%)$ consumption of the starting materials within about 30 min (entry 1). Importantly, the amount of byproducts was also dramatically reduced, albeit the stereochemical outcome was rather marginal (90:10 dr). Interestingly, extension of the reaction time from 0.5 to $2.0 \mathrm{~h}$ did not result in any visible changes of the chemical or stereochemical outcome (entry 2).

Table 2. Reaction of complex (S)-4 with $\mathrm{CF}_{3}\left(\mathrm{CH}_{2}\right)_{3} \mathrm{I}$ in DMF using solid $\mathrm{NaOMe}(28 \%$ and $10 \%$ solution in $\mathrm{MeOH})$ as a base ${ }^{[a]}$.

\begin{tabular}{|c|c|c|c|c|c|c|c|c|}
\hline \multirow[b]{2}{*}{ Entry } & \multirow[b]{2}{*}{ Time (h) } & \multirow[b]{2}{*}{ NaOMe (Concentration) } & \multicolumn{4}{|c|}{ Compounds } & \multicolumn{2}{|c|}{ Byproducts } \\
\hline & & & $4(\%)$ & $6(\%)$ & $7(\%)$ & Dr (6:7) & $5(\%)$ & $8+\mathrm{uk}^{[\mathrm{b}]}(\%)$ \\
\hline 1 & 0.5 & $28 \%$ & 0.9 & 81.3 & 9.0 & $90: 10$ & 1.15 & 0.2 \\
\hline 2 & 2.0 & $28 \%$ & $<0.1$ & 82.1 & 9.1 & $90: 10$ & 1.8 & 0.35 \\
\hline 3 & 0.5 & $10 \%$ & 0.2 & 89.05 & 3.2 & $97: 3$ & 0.3 & 2.5 \\
\hline 4 & 2.0 & $10 \%$ & 0.2 & 89.3 & 3.25 & $96.5: 3.5$ & 0.35 & 3.7 \\
\hline
\end{tabular}

[a] Reaction conditions: complex (S)-4, DMF ( $7 v / w), \mathrm{NaOMe} / \mathrm{MeOH}$ (1.0 equiv), $\mathrm{CF}_{3}\left(\mathrm{CH}_{2}\right) \mathrm{I}$ (1.0 equiv). Isolated yield of 6 was $87.5 \%$. ${ }^{[b]}$ unknown compounds.

Additional experiments with combination of $\mathrm{DMF} / \mathrm{NaOMe}$ indicated that the application of less concentrated solution of $\mathrm{NaOMe}$, has some advantageous effect on the reaction outcome. As shown in Table 2 (entry 3), the use of $10 \% \mathrm{NaOMe}$ solution in $\mathrm{MeOH}$ as a base resulted in almost complete alkylation of glycine complex (S)-4 with $\mathrm{CF}_{3}\left(\mathrm{CH}_{2}\right)_{3} \mathrm{I}$ in less than 30 min of the reaction time. Similar to the previous experiments (entries 1 and 2) the alkylation proceeded rather cleanly, but most notably with rather improved diastereoselectivity ( $97: 3 \mathrm{dr}$ ). Also in this case, the extended reaction time has no detrimental effect on the overall outcome. Using these conditions we were able to isolate diastereomerically pure major product 6 with reasonably good chemical yield of $87.5 \%$. Diastereomers $(S, 2 S)-\mathbf{6}$ and $(S, 2 R)-7$ were purified by column and fully characterized. The major product $(S, 2 S)-\mathbf{6}$ gave $[\alpha]^{25} \mathrm{D}=+2616$, indicating $\alpha-(S)$ configuration of the $\mathrm{CF}_{3}-\mathrm{AA}$, while the minor diastereomer showed a negative sign of optical rotation $\left([\alpha]^{25} \mathrm{D}=-1998\right)$, confirming $\alpha-(R)$ stereochemistry of the AA residue. 
The obtained data are in agreement of general trends in optical rotation observed for diastereomeric $\mathrm{Ni}(\mathrm{II})$-complexes of this type $[1 \mathrm{f}, 5 \mathrm{i}, 20]$.

As presented in Scheme 4, the disassembly of purified diastereomerically pure ( $>98 \%$ de) major product $(S, 2 S)-6$ was performed under the action of $3 \mathrm{~N}$ aqueous $\mathrm{HCl}$ at $60^{\circ} \mathrm{C}$ using dimethoxyethane (DME) as organic solvent. Virtually complete disappearance of complex $(S, 2 S)-6$ was observed within about $2 \mathrm{~h}$ of the reaction time. Upon cooling of the reaction mixture, the precipitate of salt of ligand (S)-5 was conveniently removed by filtration. The aqueous solution of the $\mathrm{Ni}(\mathrm{II})$ ions and free (S)-1, was concentrated, and treated with Fmoc-OSu in $\mathrm{MeCN} / \mathrm{H}_{2} \mathrm{O}$ to provide the $\mathrm{N}$-Fmoc protected amino $\operatorname{acid}(S)-9$.

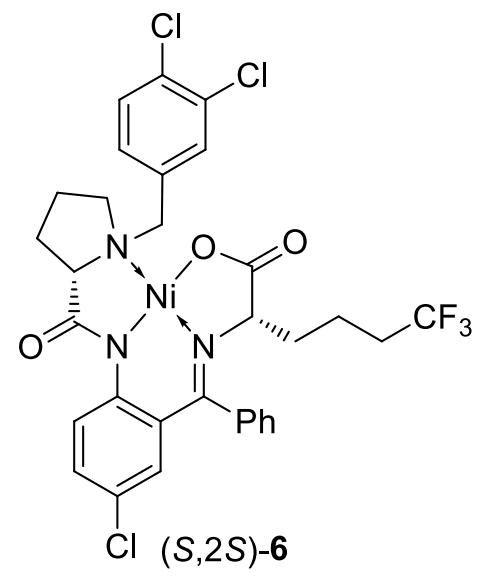<smiles>C[N+]([NH3+])([O-])[C@H]1CCCN1Cc1ccc(Cl)c(Cl)c1</smiles>

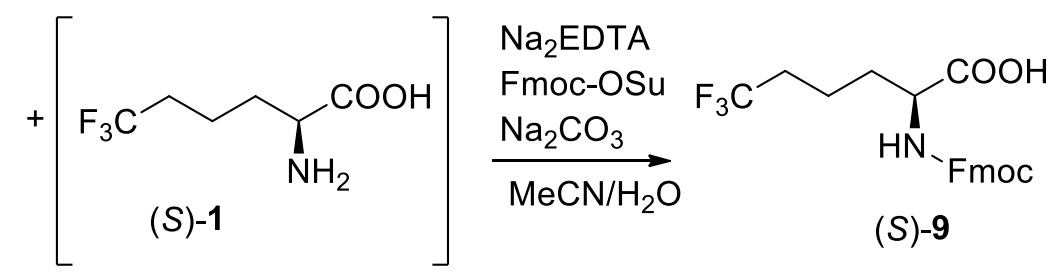

Scheme 4. Disassembly of diastereomerically pure $(S, 2 S)-6$, recovery of chiral ligand $(S)-5$, and isolation of Fmoc-(S)-6,6,6-trifluoro-norleucine 9.

\section{Conclusions}

In summary, it was found that the application of new generation of chiral glycine equivalent (S)-4, prepared from commercially available ligand (S)-5, allows for convenient preparation of Fmoc-(S)-6,6,6-trifluoro-norleucine via alkylation reaction with $\mathrm{CF}_{3}\left(\mathrm{CH}_{2}\right)_{3} \mathrm{I}$. This protocol was consistently reproduced for synthesis of the target AA on $\sim 10 \mathrm{~g}$ scale.

Supplementary Materials: The following are available online at http://www.mdpi.com/2073-8994/11/4/578/s1, Experimental procedures, full spectroscopic data for compounds 6, 7, and 9, and copies of ${ }^{1} \mathrm{H} \mathrm{NMR},{ }^{13} \mathrm{C},{ }^{19} \mathrm{~F} N M R$, and HPLC spectra (PDF).

Author Contributions: Conceptualization, H.M. and H.A.; Methodology, T.M.; Validation, H.M., Z.Y., and H.A.; Investigation, T.M.; Writing—Original Draft Preparation, J.H.; Writing—Review and Editing, V.A.S.; Supervision, H.M.

Funding: This research received no external funding.

Acknowledgments: We gratefully acknowledge the financial support from the National Natural Science Foundation of China (No. 21761132021) and IKERBASQUE, Basque Foundation for Science.

Conflicts of Interest: The authors declare no conflicts of interest. 


\section{References}

1. Henninot, A.; Collins, J.C.; Nuss, J.M. The current state of peptide drug discovery: Back to the future? J. Med. Chem. 2018, 61, 1382-1414. [CrossRef]

2. Blaskovich, M.A.T. Unusual amino acids in medicinal chemistry. J. Med. Chem. 2016, 59, 10807-10836. [CrossRef] [PubMed]

3. Ma, J.S. Unnatural amino acids in drug discovery. Chim. Oggi 2003, 21, 65-68.

4. Hodgson, D.R.W.; Sanderson, J.M. The synthesis of peptides and proteins containing non-natural amino acids. Chem. Soc. Rev. 2004, 33, 422-430. [CrossRef]

5. Sato, T.; Izawa, K.; Aceña, J.L.; Liu, H.; Soloshonok, V.A. Tailor-Made $\alpha$-Amino Acids in the Pharmaceutical Industry: Synthetic Approaches to (1R, 2S)-1-Amino-2-vinylcyclopropane-1-carboxylic Acid (Vinyl-ACCA). Eur. J. Org. Chem. 2016, 2757-2774. [CrossRef]

6. Sorochinsky, A.E.; Aceña, J.L.; Moriwaki, H.; Sato, T.; Soloshonok, V.A. Asymmetric synthesis of $\alpha$-amino acids via homologation of Ni (II) complexes of glycine Schiff bases; Part 1: Alkyl halide alkylations. Amino Acids 2013, 45, 691-718. [CrossRef] [PubMed]

7. Soloshonok, V.A.; Izawa, K. Asymmetric Synthesis and Application of alpha-Amino Acids; ACS Symposium Series 1009; Oxford University Press: Oxford, UK, 2009.

8. Soloshonok, V.A.; Sorochinsky, A.E. Practical Methods for the Synthesis of Symmetrically $\alpha, \alpha$-Disubstituted$\alpha$-Amino Acids. Synthesis 2010, 14, 2319-2344. [CrossRef]

9. Zhou, Y.; Wang, J.; Gu, Z.; Wang, S.; Zhu, W.; Aceña, J.L.; Soloshonok, V.A.; Izawa, K.; Liu, H. Next Generation of Fluorine-Containing Pharmaceuticals, Compounds Currently in Phase II-III Clinical Trials of Major Pharmaceutical Companies: New Structural Trends and Therapeutic Areas. Chem. Rev. 2016, 116, 422-518. [CrossRef]

10. Soloshonok, V.A.; Cai, C.; Hruby, V.J.; Meervelt, L.V. Asymmetric Synthesis of Novel Highly Sterically Constrained (2S,3S)-3-Methyl-3-Trifluoromethyl- and (2S,3S,4R)-3-Trifluoromethyl-4-Methylpyroglutamic Acids. Tetrahedron 1999, 55, 12045-12058. [CrossRef]

11. Wang, J.; Sánchez-Roselló, M.; Aceña, J.L.; del Pozo, C.; Sorochinsky, A.E.; Fustero, S.; Soloshonok, V.A.; Liu, H. Fluorine in Pharmaceutical Industry: Fluorine-Containing Drugs Introduced to the Market in the Last Decade (2001-2011). Chem. Rev. 2014, 114, 2432-2506. [CrossRef]

12. Zhu, W.; Wang, J.; Wang, S.; Gu, Z.; Aceña, J.L.; Izawa, K.; Liu, H.; Soloshonok, V.A. Recent advances in the trifluoromethylation methodology and new CF3-containing drugs. J. Fluorine Chem. 2014, 167, 37-54. [CrossRef]

13. Smits, R.; Cadicamo, C.D.; Burger, K.; Koksch, B. Synthetic strategies to $\alpha$-trifluoromethyl and $\alpha$-difluoromethyl substituted $\alpha$-amino acids. Chem. Soc. Rev. 2008, 37, 1727-1739. [CrossRef] [PubMed]

14. Kukhar, V.P.; Sorochinsky, A.E.; Soloshonok, V.A. Practical synthesis of fluorine containing alpha- and beta-amino acids: Recipes from Kiev, Ukraine. Future Med. Chem. 2009, 1, 793-819. [CrossRef] [PubMed]

15. Sorochinsky, A.E.; Soloshonok, V.A. Asymmetric synthesis of fluorine-containing amines, amino alcohols, $\alpha$ and $\beta$-amino acids mediated by chiral sulfinyl group. J. Fluorine Chem. 2010, 131, 127-139. [CrossRef]

16. Tarui, A.; Sato, K.; Omote, M.; Kumadaki, I.; Ando, A. Stereoselective synthesis of $\alpha$-fluorinated amino acid derivatives. Adv. Synth. Catal. 2010, 352, 2733-2744. [CrossRef]

17. Czekelius, C.; Tzschucke, C.C. Synthesis of halogenated carboxylic acids and amino acids. Synthesis 2010, 4, 543-566. [CrossRef]

18. Qiu, X.-L.; Qing, F.-L. Recent advances in the synthesis of fluorinated amino acids. Eur. J. Org. Chem. 2011, 2011, 3261-3278. [CrossRef]

19. Turcheniuk, K.V.; Kukhar, V.P.; Roeschenthaler, G.-V.; Acena, J.L.; Soloshonok, V.A.; Sorochinsky, A.E. Recent advances in the synthesis of fluorinated aminophosphonates and aminophosphonic acids. RSC Adv. 2013, 3, 6693-6716. [CrossRef]

20. Aceña, J.L.; Sorochinsky, A.E.; Soloshonok, V.A. Recent Advances in the Asymmetric Synthesis of $\alpha$-(Trifluoromethyl)-Containing $\alpha$-Amino Acids. Synthesis 2012, 44, 1591-1602. [CrossRef]

21. Aceña, J.L.; Sorochinsky, A.E.; Moriwaki, H.; Sato, T.; Soloshonok, V.A. Synthesis of fluorine containing $\alpha$-amino acids in enantiomerically pure form via homologation of $\mathrm{Ni}(\mathrm{II})$ complexes of glycine and alanine Schiff bases. J. Fluorine Chem. 2013, 155, 21-38. [CrossRef] 
22. Mikami, K.; Fustero, S.; Sánchez-Roselló, M.; Aceña, J.L.; Soloshonok, V.A.; Sorochinsky, A.E. Synthesis of fluorinated beta-amino acids. Synthesis 2011, 19, 3045-3079.

23. Han, J.; Sorochinsky, A.E.; Ono, T.; Soloshonok, V.A. Biomimetic Transamination-A Metal-Free Alternative to the Reductive Amination. Application for Generalized Preparation of Fluorine-Containing Amines and Amino Acids. Curr. Org. Synth. 2011, 8, 281-294. [CrossRef]

24. Aceña, J.L.; Simon-Fuentes, A.; Santos, F. Recent Developments in the Synthesis of Fluorinated $\beta$-Amino Acids. Curr. Org. Chem. 2010, 14, 928-949. [CrossRef]

25. Dhillon, S. Ivosidenib: First Global Approval. Drugs 2018, 78, 1509-1516. [CrossRef]

26. Urquhart, L. FDA new drug approvals in Q3 2018. Nat. Rev. Drug Discov. 2018, 17, 799.

27. Scott, L.J. Eravacycline: A Review in Complicated Intra-Abdominal Infections. Drugs 2019, 79, 315-324. [CrossRef] [PubMed]

28. Shirley, M. Dacomitinib: First Global Approval. Drugs 2018, 78, 1947-1953. [CrossRef] [PubMed]

29. Tsushima, T.; Kawada, K.; Ishihara, S.; Uchida, N.; Shiratori, O.; Higaki, J.; Hirata, M. Fluorine containing amino acids and their derivatives. 7. Synthesis and antitumor activity of $\alpha$ - and $\gamma$-substituted methotrexate analogs. Tetrahedron 1988, 44, 5375-5387. [CrossRef]

30. Shu, M.; Yu, R.; Zhang, Y.; Wang, J.; Yang, L.; Wang, L.; Lin, Z. Predicting the activity of antimicrobial peptides with amino acid topological information. Med. Chem. 2013, 9, 32-44. [CrossRef] [PubMed]

31. Ojima, I.; Jameison, F.A.; Pete, B.; Radunz, H.; Schittenhelm, C.; Lindner, H.J.; Emith, A.E. Design, synthesis and enzyme inhibitory activities of new trifluoromethyl-containing inhibitors for angiotensin converting enzyme. Drug Des. Discov. 1994, 11, 91-113. [PubMed]

32. Borozan, S.Z.; Zlatović, M.V.; Stojanović, S.Đ. Anion- $\pi$ interactions in complexes of proteins and halogen-containing amino acids. J. Biol. Inorg. Chem. 2016, 21, 357-368. [CrossRef] [PubMed]

33. Sandberg, M.; Eriksson, L.; Jonsson, J.; Sjöström, M.; Wold, S. New Chemical Descriptors Relevant for the Design of Biologically Active Peptides. A Multivariate Characterization of 87 Amino Acids. J. Med. Chem. 1998, 41, 2481-2491. [CrossRef] [PubMed]

34. van Hest, J.C.M.; Kiick, K.L.; Tirrell, D.A. Efficient Incorporation of Unsaturated Methionine Analogues into Proteins in Vivo. J. Am. Chem. Soc. 2000, 122, 1282-1288. [CrossRef]

35. Kiick, K.L.; Tirrell, D.A. Protein Engineering by In Vivo Incorporation of Non-Natural Amino Acids: Control of Incorporation of Methionine Analogues by Methionyl-tRNA Synthetase. Tetrahedron 2000, 56, 9487-9493. [CrossRef]

36. Borozan, S.Z.; Stojanović, S.Đ. Halogen bonding in complexes of proteins and non-natural amino acids. Comput. Biol. Chem. 2013, 47, 231-239. [CrossRef] [PubMed]

37. Wadhwani, P.; Strandberg, E.; Heidenreich, N.; Bürck, J.; Fanghänel, S.; Ulrich, A.S. Self-Assembly of Flexible $\beta$-Strands into Immobile Amyloid-Like $\beta$-Sheets in Membranes As Revealed by Solid-State 19F NMR. J. Am. Chem. Soc. 2012, 134, 6512-6515. [CrossRef]

38. Tkachenko, A.N.; Mykhailiuk, P.K.; Afonin, S.; Radchenko, D.S.; Kubyshkin, V.S.; Ulrich, A.S.; Komarov, I.V. ${ }^{19}$ F NMR Label to Substitute Polar Amino Acids in Peptides: A CF3-Substituted Analogue of Serine and Threonine. Angew. Chem. Int. Ed. 2013, 52, 1486-1489. [CrossRef]

39. Gfeller, D.; Michielin, O.; Zoete, V. Expanding molecular modeling and design tools to non-natural sidechains. J. Comput. Chem. 2012, 33, 1525-1535. [CrossRef]

40. Li, S.G.; Portela-Cubillo, F.; Zard, S.Z. A Convergent Synthesis of Enantiopure Open-Chain, Cyclic, and Fluorinated $\alpha$-Amino Acids. Org. Lett. 2016, 18, 1888-1891. [CrossRef]

41. Ojima, I.; Kato, K.; Nakahashi, K.; Fuchikami, T.; Fujita, M. New and effective routes to fluoro analogs of aliphatic and aromatic amino acids. J. Org. Chem. 1989, 54, 4511-4522. [CrossRef]

42. Soloshonok, V.A.; Kukhar, V.P. Biomimetic Transamination of $\alpha$-Keto Perfluorocarboxylic Esters. An Efficient Preparative Synthesis of $\beta, \beta, \beta$-Trifluoroalanine. Tetrahedron 1997, 53, 8307-8314. [CrossRef]

43. Soloshonok, V.A.; Kirilenko, A.G.; Kukhar, V.P.; Resnati, G. Transamination of Fluorinated $\beta$-Keto Carboxylic Esters. A Biomimetic Approach to $\beta$-Polyfluoroalkyl- $\beta$-Amino Acids. Tetrahedron Lett. 1993, 34, 3621-3624. [CrossRef]

44. Peng, W.; Wan, J.; Xie, B.; Ma, X. 9-Amino-(9-deoxy) cinchona alkaloid-derived new chiral phase-transfer catalysts. Org. Biomol. Chem. 2014, 12, 8336-8345. [CrossRef] [PubMed] 
45. Scott, W.L.; Alsina, J.; Audu, C.O.; Babaev, E.; Cook, L.; Dage, J.L.; Goodwin, L.A.; Martynow, J.G.; Matosiuk, D.; Royo, M.; et al. Distributed Drug Discovery, Part 2: Global Rehearsal of Alkylating Agents for the Synthesis of Resin-Bound Unnatural Amino Acids and Virtual D ${ }^{3}$ Catalog Construction. J. Comb. Chem. 2009, 11, 14-33. [CrossRef]

46. Yajima, T.; Nagano, H. Photoinduced Diastereoselective Addition of Perfluoroalkyl Iodides to Acrylic Acid Derivatives for the Synthesis of Fluorinated Amino Acids. Org. Lett. 2007, 9, 2513-2515. [CrossRef]

47. Larsson, U.; Carlson, R.; Leroy, J. Synthesis of amino acids with modified principal properties 1. Amino acids with fluorinated side chains. Acta Chem. Scand. 1993, 47, 380-390. [CrossRef]

48. Wang, J.; Lin, D.; Zhou, S.; Soloshonok, V.A.; Liu, H. Asymmetric Synthesis of Sterically Constrained Linear Trifluoromethyl Containing Amino Acids via Alkylation of Chiral Equivalents of Nucleophilic Glycine and Alanine. J. Org. Chem. 2011, 76, 684-687. [CrossRef] [PubMed]

49. Soloshonok, V.A.; Gerus, I.I.; Yagupolskii, Y.L.; Kukhar, V.P. Fluorine-Containing Amino Acids. III. $\alpha$-Trifluoromethyl- $\alpha$-Amino Acids. Zh. Org. Khim. 1987, 23, 2308-2313.

50. Soloshonok, V.A.; Ohkura, H.; Yasumoto, M. Operationally Convenient Asymmetric Synthesis of $(S)$ and (R)-3-Amino-4,4,4-trifluorobutanoic Acid. Part II: Enantioselective Biomimetic Transamination of 4,4,4-Trifluoro-3-oxo-N-[(R)-1-phenylethyl)butanamide. J. Fluorine Chem. 2006, 127, 930-935. [CrossRef]

51. Röschenthaler, G.-V.; Kukhar, V.P.; Kulik, I.B.; Belik, M.Y.; Sorochinsky, A.E.; Rusanov, E.B.; Soloshonok, V.A. Asymmetric synthesis of phosphonotrifluoroalanine and its derivatives using N-tert-butanesulfinyl imine derived from fluoral. Tetrahedron Lett. 2012, 53, 539-542. [CrossRef]

52. Turcheniuk, K.V.; Poliashko, K.O.; Kukhar, V.P.; Rozhenko, A.B.; Soloshonok, V.A.; Sorochinsky, A.E. Efficient asymmetric synthesis of trifluoromethylated $\beta$-aminophosphonates and their incorporation into dipeptides. Chem. Commun. 2012, 48, 11519-11521. [CrossRef] [PubMed]

53. Soloshonok, V.A.; Cai, C.; Hruby, V.J. A Practical Asymmetric Synthesis of Enantiomerically Pure 3-Substituted Pyroglutamic Acids and Related Compounds. Angew. Chem. Int. Ed. 2000, 39, 2172-2175. [CrossRef]

54. Yamada, T.; Okada, T.; Sakaguchi, K.; Ohfune, Y.; Ueki, H.; Soloshonok, V.A. Efficient Asymmetric Synthesis of Novel 4-Substituted and Configurationally Stable Analogs of Thalidomide. Org. Lett. 2006, 8, 5625-5628. [CrossRef] [PubMed]

55. Han, J.; Kitagawa, O.; Wzorek, A.; Klika, K.D.; Soloshonok, V.A. The self-disproportionation of enantiomers (SDE): A menace or an opportunity? Chem. Sci. 2018, 9, 1718-1739. [CrossRef]

56. Han, J.; Nelson, D.J.; Sorochinsky, A.E.; Soloshonok, V.A. Self-Disproportionation of Enantiomers via Sublimation; New and Truly Green Dimension in Optical Purification. Curr. Org. Synth. 2011, 8, 310-317. [CrossRef]

57. Han, J.; Wzorek, A.; Kwiatkowska, M.; Soloshonok, V.A.; Klika, K.D. The self-disproportionation of enantiomers (SDE) of amino acids and their derivatives. Amino Acids 2019. [CrossRef] [PubMed]

58. Aceña, J.L.; Sorochinsky, A.E.; Soloshonok, V.A. Asymmetric synthesis of $\alpha$-amino acids via homologation of $\mathrm{Ni}(\mathrm{II})$ complexes of glycine Schiff bases. Part 3: Michael addition reactions and miscellaneous transformations. Amino Acids 2014, 46, 2047-2073. [CrossRef] [PubMed]

59. Sorochinsky, A.E.; Aceña, J.L.; Moriwaki, H.; Sato, T.; Soloshonok, V.A. Asymmetric synthesis of $\alpha$-amino acids via homologation of $\mathrm{Ni}(\mathrm{II})$ complexes of glycine Schiff bases. Part 2: Aldol, Mannich addition reactions, deracemization and (S) to (R) interconversion of $\alpha$-amino acids. Amino Acids 2013, 45, 1017-1033. [CrossRef] [PubMed]

60. Wang, Y.; Song, X.; Wang, J.; Moriwaki, H.; Soloshonok, V.A.; Liu, H. Recent approaches for asymmetric synthesis of $\alpha$-amino acids via homologation of Ni(II) complexes. Amino Acids 2017, 49, 1487-1520. [CrossRef] [PubMed]

61. Ellis, T.K.; Ueki, H.; Yamada, T.; Ohfune, Y.; Soloshonok, V.A. The Design, Synthesis and Evaluation of a New Generation of Modular Nucleophilic Glycine Equivalents for the Efficient Synthesis of Sterically Constrained $\alpha$-Amino Acids. J. Org. Chem. 2006, 71, 8572-8578. [CrossRef]

62. Soloshonok, V.A.; Ueki, H.; Ellis, T.K.; Yamada, T.; Ohfune, Y. Application of Modular Nucleophilic Glycine Equivalents for Truly Practical Asymmetric Synthesis of $\beta$-Substituted Pyroglutamic Acids. Tetrahedron Lett. 2005, 46, 1107-1110. [CrossRef]

63. Soloshonok, V.A.; Ellis, T.K.; Ueki, H.; Ono, T. Resolution/Deracemization of Chiral $\alpha$-Amino Acids Using Resolving Reagents with Flexible Stereogenic Centers. J. Am. Chem. Soc. 2009, 131, 7208-7209. [CrossRef] 
64. Takeda, R.; Kawamura, A.; Kawashima, A.; Sato, T.; Moriwaki, H.; Izawa, K.; Akaji, K.; Wang, S.; Liu, H.; Aceña, J.L.; et al. Chemical Dynamic Kinetic Resolution and (S)/(R)-Interconversion of Unprotected $\alpha$-Amino Acids. Angew. Chem. Int. Ed. 2014, 53, 12214-12217. [CrossRef]

65. Bergagnini, M.; Fukushi, K.; Han, J.; Shibata, N.; Roussel, C.; Ellis, T.K.; Aceña, J.L.; Soloshonok, V.A. NH-type of chiral Ni(II) complexes of glycine Schiff base: Design, structural evaluation, reactivity and synthetic applications. Org. Biomol. Chem. 2014, 12, 1278-1291. [CrossRef]

66. Nian, Y.; Wang, J.; Moriwaki, H.; Soloshonok, V.A.; Liu, H. Analysis of crystallographic structures of Ni(II) complexes of $\alpha$-amino acid Schiff bases; Elucidation of the substituents effect on stereochemical preferences. Dalton Trans. 2017, 46, 4191-4198. [CrossRef]

67. Tang, X.; Soloshonok, V.A.; Hruby, V.J. Convenient Asymmetric Synthesis of Enantiomerically Pure $2^{\prime}, 6^{\prime}$-Dimethyltyrosine (DMT) via Alkylation of Chiral Nucleophilic Glycine Equivalent. Tetrahedron Asymmetry 2000, 11, 2917-2925. [CrossRef]

68. Nian, Y.; Wang, J.; Zhou, S.; Wang, S.; Moriwaki, H.; Kawashima, A.; Soloshonok, V.A.; Liu, H. Recyclable Ligands for the Non-Enzymatic Dynamic Kinetic Resolution of Challenging $\alpha$-Amino Acids. Angew. Chem. Int. Ed. 2015, 54, 12918-12922. [CrossRef] [PubMed]

69. Nian, Y.; Wang, J.; Zhou, S.; Dai, W.; Wang, S.; Moriwaki, H.; Kawashima, A.; Soloshonok, V.A.; Liu, H. Purely Chemical Approach for Preparation of D-alpha-amino Acids via (S)-to-(R)-interconversion of Unprotected Tailor-made alpha-amino Acids. J. Org. Chem. 2016, 81, 3501-3508. [CrossRef] [PubMed]

70. Zhou, S.; Wang, J.; Chen, X.; Aceña, J.L.; Soloshonok, V.A.; Liu, H. Chemical Kinetic Resolution of Unprotected $\beta$-Substituted- $\beta$-Amino Acids Using Recyclable Chiral Ligands. Angew. Chem. Int. Ed. 2014, 53, 7883-7886. [CrossRef] [PubMed]

71. Mei, H.; Hiramatsu, T.; Takeda, R.; Moriwaki, H.; Abe, H.; Han, J.; Soloshonok, V.A. Expedient Asymmetric Synthesis of (S)-2-Amino-4,4,4-trifluorobutanoic Acid via Alkylation of Chiral Nucleophilic Glycine Equivalent. Org. Process. Res. Dev. 2019. [CrossRef]

72. Romoff, T.T.; Palmer, A.B.; Mansour, N.; Creighton, C.J.; Miwa, T.; Ejima, Y.; Moriwaki, H.; Soloshonok, V.A. Scale-up Synthesis of (R)- and (S)-N-(2-benzoyl-4-chlorophenyl)-1-(3,4-dichlorobenzyl)pyrrolidine2-carboxamide hydrochloride, a Versatile Reagent for Preparation of Tailor-made $\alpha$ - and $\beta$-Amino Acids in Enantiomerically Pure Form. Org. Process. Res. Dev. 2017, 21, 732-739. [CrossRef]

73. Ueki, H.; Ellis, T.K.; Martin, C.H.; Soloshonok, V.A. Efficient Large-Scale Synthesis of Picolinic Acid Derived Ni(II)-Complexes of Glycine. Eur. J. Org. Chem. 2003, 2003, 1954-1957. [CrossRef]

74. Ellis, T.K.; Hochla, V.M.; Soloshonok, V.A. Efficient Synthesis of 2-Aminoindane-2-Carboxylic Acid via Dialkylation of Nucleophilic Glycine Equivalent. J. Org. Chem. 2003, 68, 4973-4976. [CrossRef] [PubMed]

75. Houck, D.; Aceña, J.L.; Soloshonok, V.A. Alkylations of Chiral Nickel(II) Complexes of Glycine under Phase-Transfer Conditions. Helv. Chim. Acta 2012, 95, 2672-2679. [CrossRef]

76. Soloshonok, V.A.; Ueki, H. Design, Synthesis and Characterization of Binuclear Ni(II) Complexes with Inherent Helical Chirality. J. Am. Chem. Soc. 2007, 129, 2426-2427. [CrossRef]

77. Soloshonok, V.A.; Ono, T.; Ueki, H.; Vanthuyne, N.; Balaban, T.S.; Bürck, J.; Fliegl, H.; Klopper, W.; Naubron, J.V.; Tam, T.T.; et al. Ridge-tile-like chiral topology: Synthesis, resolution and complete chiroptical characterization of enantiomers of edge-sharing binuclear square planar complexes of $\mathrm{Ni}$ (II) bearing achiral ligands. J. Am. Chem. Soc. 2010, 132, 10477-10483. [CrossRef]

(C) 2019 by the authors. Licensee MDPI, Basel, Switzerland. This article is an open access article distributed under the terms and conditions of the Creative Commons Attribution (CC BY) license (http://creativecommons.org/licenses/by/4.0/). 